\title{
The Dodo Cult, Witchcraft, and Secondary Marriage in Irigwe, Nigeria ${ }^{1}$
}

Walter H. Sangree

\author{
University of Rochester
}

The Dodo Cults, like the famous cargo cults of Melanesia, are an indigenous response to social changes which indirectly have been fostered by Western social and cultural agencies. However, unlike some cargo cults in Melanesia, the Dodo Cult, at least as manifest in Irigwe, is not an attempt to attain the political power and material glories of the western world. Instead, one of the Dodo Cult's principal aims is explicitly that of assuring the health and well being of cultists, particularly of their infants and small children. A secondary, but crucial, function of the cult is to decrease the tendency for wives to shift residence to other husbands, thereby increasing marriage stability. Irigwe men, when discussing the importance of the Dodo Cult, universally view it as a way of helping control disease, and some of them also say it helps keep wives in residence. ${ }^{2}$

The Irigwe, an agricultural tribe of around I7,000 people, with its own distinctive language and culture, was first pacified by the British in 1905 . The tribe has been increasingly exposed to European contact since then, and as of 1965 about 3 per cent of the Irigwe regard themselves as Christians. Nevertheless, the large majority of the Irigwe, male and female, young and old, still pass most of their everyday lives guided and fully engaged by the circle of agricultural, domestic, and ceremonial activities prescribed by the traditional Irigwe calendar and by their time-honored notions of social responsibility and the "good life."

Irigwe traditionally had no tribal chief, and lacked any formalized political hierarchy as such. Instead the tribe was subdivided into 25 ritual units or "sections" (rekla). Each section had responsibility for one or another ritual specialty of importance to the entire tribe. The 25 Irigwe ritual sections openly competed with one another, both in taking wives from other sections in secondary marriage, and also in trying to have the greatest number of "heroes," i.e., men who had gained recognition for killing dangerous animals classed as "big game," or for taking the head of an enemy tribesman in a headhunting expedition. Thus it is striking that prolonged inter-section squabbles were rare, and that inter-section feuding and homicide were unheard of.

Two factors were, and have remained until recently, crucial to this traditional tribal unity and freedom from feuding. First, the 25 sections are 
ritually united by each section's having exclusive responsibility for one or more of the many rituals which are concerned with farming, hunting, and health, and which are believed to be necessary or very important for the well being of the tribe as a whole. Second, cross-cutting affinal and cognatic bonds mediated by the Irigwe's system of both primary and secondary marriage (Sangree 1972: 1237-8) serve strongly to suppress inter-section violence.

The British in Ig05 suppressed by might of arms all Irigwe participation in inter-tribal warfare and headhunting. In keeping with their general policy of indirect rule, the British quickly organized the Irigwe into two tribal Districts, one comprised of those Irigwe sections located south of the River Ngell, and the other of the sections north of the Ngell, and in each case they appointed a man from the largest section in his District to be the chief, or "District Head," as he was officially called. The two Districts were in turn each subdivided into four Sub-districts, each with an appointed Headman responsible to the Head of his District. Each Sub-district included people from several of the traditional ritual sections, with the latter, as such, having no set place or function in the new administrative hierarchy.

This tribal administrative system from the outset proved effective in curbing the Irigwe penchant for headhunting with neighboring tribes. Through the years it has become an accepted vehicle not only for maintaining the tribe's recognition of the Colonial Administration's (and since I960 the Nigerian Government's) overrule and tax-collecting prerogatives, but in recent years it has also become the principal mechanism for assuring intra-tribal harmony, and for settling inter-section disputes.

The sectional system of ritual responsibilities, and inter-section competition in hunting of big game and in wife-taking in secondary marriage were all still in full swing and participated in by all but the Christian minority during the period of my field research (1963-65). It is my belief that the development of the tribal administrative bureaucracy has rendered these section-related activities politically nonfunctional. They continue largely unabated, however, and a strong case can be made for their continuing functional value in other realms of Irigwe social organization. Control of the weather and assurance of successful crop growth and harvest are achieved according to Irigwe belief by the ritual activities of the various sections. The dry season is a slack time for traditional farm work, and the tribal morale and sense of well being is certainly enhanced by the dry season hunting activities. The continuation of wife-taking is in particular buttressed by Irigwe notions concerning the cause and control of disease. Wife-taking, however, is not only nonfunctional nowadays politically, but has always been very disfunctional in a number of other ways. Thus it is to be expected that other social mechanisms would emerge both to suppress secondary marriage and take over its functions as a mechanism for controlling anxiety about disease. This is precisely the functional significance of the Dodo Cult in Irigwe today.

Elsewhere I have analyzed the Irigwe system of secondary marriage and noted the strains it places on the domestic arena, and on the psychic well 
being of women (Sangree 1969). Under the traditional Irigwe secondary marriage system, marrying a plurality of wives is a relatively simple matter, but getting some or even any of these wives to remain resident with the husband is not an easy task. Conversely, from the woman's point of view filial responsibilities towards her father and marriage guardian severely circumscribe a woman's actual autonomy, both in rejecting suitors and in remaining in residence permanently, or for long, with the husband she most prefers; for failure to meet these responsibilities is believed to be a major factor in bringing illness to herself or her offspring (Sangree 1974). Other factors permitting, a major consideration for a woman in deciding with which husband to reside is where she and her children seem to enjoy the best physical health. A congenial husband, pleasant co-wives, and a generally prosperous and attractive ambience are amenities that every woman desires, but these are meaningless without good health for herself and her children. Thus residence in a compound where she and her young offspring are relatively free from the depredations of evil spirits, witches, and other illness-producing forces are what a woman generally seeks most assiduously. This is particularly understandable in a society where more than half of the live-born infants die before reaching the age of five or six.

Troublesome spirits, called rījé, are said by Irigwe to be probably the most prevalent cause of malaise and illness among adult women. The vast majority of Irigwe women are possessed by rijé, usually after they have borne one or two children, but sometimes earlier. These spirits are not only believed to be responsible for post-partum despondency and depression, which appear to be very common in Irigwe, but are also viewed as possible causes of infertility, miscarriage, and general physical and psychic malaise. $R i j e ́$ are believed to be neutralized and controlled by possession cult activities which include costly dancing and feasting ceremonials. A woman troubled by rījé can be expected to move from one husband to another until she finds one willing to arrange and pay for such a ceremonial on her behalf (Sangree 1969 ). Rijé are not considered a direct factor in the illness and mortality of infants and small children; rather it is witchcraft (tsitsie) which is suspected in such cases.

\section{IRIGWE WITCHCRAFT}

Irigwe view witchcraft as being very significant in both tribal and local or family affairs. At the tribal level witchcraft enters into both ritual and political matters, and its practitioners are characteristically men. It may bring pestilence and other disasters, but it is also regarded as an important asset to be utilized in strengthening the tribe's offensive and defensive efforts in inter-tribal affrays (Sangree 1970, 197I). In the local arena, namely among members of the extended family compound (ari), the lineage (enucie), and others living nearby, witches are often women. In both the tribal and local arenas a witch ( $k$ rotu) may utilize various kinds of sorcery as well as witchcraft power (tsitsie) to achieve desired goals.

Particularly feared in local affairs is the witchcraft practiced by some older women who, jealous of younger women's fertility and healthy chil- 
dren, are said to have apprenticed themselves to a powerful witch (krotu) and to have learned sickness dealing techniques to use against younger wives and their offspring resident in their own and neighboring compounds. On a number of occasions people told me that individuals well-known to be witches were living right in their own compounds, but such pronouncements were never made publically in my presence nor were names ever given to me. Instead of open accusations or direct action, indirect palliatives and countermeasures are normally used against the purported depredations of these witches. Many adults wear leather clad anti-witchcraft medicine bundles around their waists that can be purchased from Hausa and other non-Irigwe practitioners living in Miango, other market areas, and the towns. Local Irigwe doctors (renevo) also regularly prescribe antiwitchcraft medicines and charms. The most highly respected and sought after anti-witchcraft practitioners in Irigwe are those who are surviving twins, and thus "good" witches. The Irigwe believe that twins are always witches (rekrotui), but that one twin is "good" and the other is "bad." In former times the "bad" twin was killed shortly after birth; the surviving "good" twin has the inborn capacity to recognize and neutralize the evil power of other witches (Sangree I971). It is believed that witches seldom are motivated to trouble women and children whom they do not frequently see; thus it is common for a woman seeking safety from a witch's malevolence to move to another husband, taking her small children with her.

It is difficult indeed to estimate how often fear of witchcraft is a major motive in a woman's decision to shift residence to another husband. In the first place, with the exception of certain virulent epidemic diseases, such as smallpox and measles, most illnesses or other misfortunes are viewed as resulting from two or more factors, no one of which would necessarily in itself either produce or cure the difficulty. Second, particularly in those cases where fear of witchcraft is a major motive in moving, it is deemed wise not to voice openly one's motives for fear of inspiring the witch to greater malevolence. Thus a husband can never be certain that fear of witchcraft from someone else living in his compound or nearby might not be a factor, indeed the major factor, in a wife's leaving him to take up residence with another husband.

During the latter months of my field research in Irigwe, several men talked with me about the growing problem of witchcraft, particularly in local affairs. When I asked what was being done to control or end this problem of witchcraft, on several occasions I was told that more and more people were bringing Dodo to Irigwe for this very purpose. Witches, it was claimed, feared Dodo, and could be kept under control by him.

\section{The Dodo Cult}

I first heard of Dodo early in my fieldwork from a young Christian Irigwe who spoke of it when I asked him if there were any masked dancers in Irigwe. He said in the early 195 os, when he was a boy, his father and a number of others in his extended family compound had belonged to a cult called "Dodo," very important in a number of tribes in Zaria Province. ${ }^{3}$ 
Then in the middle of 1950, all Dodo Cult activity in his compound ended because of a Provincial Government edict outlawing Dodo in Plateau Province. Apparently there had been an increasing number of instances on the Plateau where Dodo cultists had terrorized nonmembers for one reason or another. Because of this Christian informant's account I assumed that Dodo was a thing of the past in Irigwe, and for a number of months I gave it no thought.

About a year later, when I was well established in a non-Christian area of the tribe, I was quite startled when I was casually told by one of my traditionalist friends that "Dodo" was coming that night to the compound where I was residing, and that I should be sure not to sleep through it. To sleep through would indeed have been difficult. Around II:oo p.m. an eerie, reedy sound emerged from an empty hut in one corner of the compound, and almost immediately a crowd of men and women gathered around the hut entrance. A number of men entered the hut and soon the reedy sound was accompanied by the chanting of several of the men therein. About this time I tried to peer with the help of my flashlight through the two sets of rope tassles hanging at the hut's entranceway into its interior, but I was pulled away by the crowd outside and told I would die if $I$ entered, or even peeked in. It was then explained to me that only those who had been initiated into the cult ( $s i$ zongru dodo) could enter the hut. Only men could be initiated; each initiate had to pay a fee of one goat, six shillings, and two hens, and the initiate was obliged to swear never to reveal to the uninitiated what went on in the Dodo hut. I later learned that before Dodo had been banned by the Government there had been several instances of Dodo cultists' severely beating other members who had revealed cult secrets to noninitiates.

Several months later at the end of the dry season in 1965 , after the annual pan-tribal hunting festival (Zaraci), a rash of Dodo activity swept Irigwe. This is the time of year when the days are often hot and muggy and people are beginning to prepare the soil for planting. The granaries provided by a husband for each resident wife are about empty, and everyone is anxious about the heavy work of farming lying ahead. Also, people are troubled by the increase of illness, especially among the very young children and the aged, that accompanies the beginning of the heavy rain. It is the time of year when women are most apt to decamp and take up residence with another secondary husband. I attended several evening Dodo sessions in a number of different compounds at this time. Then one afternoon several Irigwe friends stopped by my hut and asked me if I wanted to accompany them to a compound situated in the bush about three miles from the thickly settled part of Nyango at a place called Raenwíe Nku. When we arrived at the clearing in front of the compound's entrance we saw a circle of women and girls chanting and shuffing in a counterclockwise direction to the accompaniment of two male drummers. Wheeling around in the center of the circle was what appeared to be nothing other than a great wriggling, gyrating stack of dried leaves. The dancer's body was completely hidden by the costume, with the arms, legs and feet totally 


\section{EthNoLogy}

submerged under the long swirls of raffia-like dried leaves. ${ }^{4}$ Short sticks protruded at either side instead of arms and hands. The costume was peaked by a small cylindrical device, like a small hat box, painted white and decorated with red designs and a few specks of black; and there were two holes presumably at the front of the device, one above the other. Suddenly it started to rain; the crowd dispersed to find shelter under the eaves of the huts of the compound, and we lost sight of the raffia figure as it scurried behind one of the huts.

The rain soon stopped, and after about 30 minutes the leafy figure appeared again from a cluster of huts alongside the main compound, and skipped and twirled up the path towards the main dance area where it had been cavorting earlier. Again two drummers appeared, and a circle of chanting and dancing girls and women quickly formed around the gyrating figure. On the edge of the dancing ground, right next to the compound, was a large new circular windowless hut which we were told had just been built for the Dodo. Smoke was rising from its thatch, indicating that a fire was burning within. Suddenly we heard a reedy voice emanating from the hut-the voice of the Dodo. I asked who the dancing raffia figure was, and was told it was the Dodo's wife-that the Dodo himself never came out of his hut. The Dodo's reedy voice could be heard more and more frequently above the chanting and drumming. Then most of the dancers stopped and watched the "Dodo's wife" dancing about, expressing their appreciation by shrill ululations. A woman stepped out and touched the raffia costume of the dancing figure with a penny, and then dropped the penny into a calabash held out by an assistant who suddenly appeared out of the crowd. A whole rash of onlookers, mostly women, followed suit, one after another. A man in the crowd exhorted me to dash the dancing "female" Dodo. One of my friends shooed him away, but then we took courage and all three of us stepped out together, and one after another we touched the twirling figure with pennies and dropped them in the calabash. The Dodo dancer stopped before us and we were told to kneel, which we did, while she held out a stick arm and uttered some gibberish in reedy tones which none of us could understand; but others in the crowd assured us she was blessing us and uttering words of praise. A few minutes earlier someone had told me that the "Dodo's wife could always spot an evil person, and if she were to touch one with her stick arm, the person touched would surely die." I felt somewhat relieved when she turned and gyrated away without having touched any of us with her waving stick arms.

A little while later the "Dodo's wife" disappeared into the Dodo hut "to feast and drink," for, it was explained to us, she got very hungry and thirsty from dancing. Men of the compound had been receiving gifts of food and beer from women all afternoon and carrying them into the hut; now a couple of men brought two big pots of beer out of the hut, and women who had been dancing and watching gathered around to drink some of this. We left about that time because it was near sunset and it would soon be difficult to find our way home. 
Later I was told that this was the first time that the Dodo (i.e. "Dodo's wife") had been allowed to dance in public view since the Government ban on Dodo a decade or so earlier. The previous autumn the people of Raenwíe Nku had applied to the Chief of Miango District in Irigwe, and through him, to the Divisional Headquarters in Jos; and upon payment of a license fee of $f, 7 / \%$ - they had finally obtained permission from the authorities for the Dodo (i.e., the "Dodo's wife") to dance abroad in their area for the current year. My friends at Tahu said they were also seeking permission, and they had been told by the Chief of Miango District that since all was going well with the Dodo dances at Raenwíe Nku, they too might soon be granted a license for her to dance at Tahu.

My field work in Irigwe ended two months later, at the end of June I965, and at that time no other Dodo groups in Irigwe had obtained permission for masked Dodo dances. I have heard, however, in letters from Irigwe friends, that since then the Dodo Cult has grown greatly in membership. In I 969 I was told that a large number of compounds now had Dodo huts, and that masked Dodo dances had become fairly widespread, although they were still under strict governmental licensing and supervision. My first-hand knowledge of the Dodo Cult in Irigwe is very limited, both because it was just getting under way again when I was there, and also because my entrée to Dodo activities was limited principally to the compound where I lived in Brari Tahu; and it was further restricted even in Brari Tahu by the constraints of secrecy placed upon initiated members of the cult. Nevertheless, I believe considerable insight into the social significance of Dodo Cult activities, and thus into its rising popularity, can be gained by describing in some detail the last Dodo Cult meeting I attended in Brari Tahu, and by reviewing briefly the Tahu cultists' account of the origin and importance of Dodo activity in that particular compound.

\section{A Dodo Cult Meeting}

On Saturday night, June I2, I965, a big Dodo dance was held at Brari Tahu. Word had gone out several days before from the elders of Brari Rae that they would hold within a week or so the crucial ceremonial ending all dry season activities ( $c$ i rongru) which tabus all outdoor fires, drumming, and outdoor celebrations for the duration of the farming season. Thus most of the Dodo Cult centers in Irigwe held a dance that Saturday night as a final tribute to the Dodo before the coming restrictions on outside fires and drumming would make this impossible. By ro:oo p.m. a few men belonging to the cult in Brari Tahu had already gathered in front of the newly constructed Dodo hut situated in a corner of the compound, and shortly thereafter women began arriving with calabashes of a choice dish called kpewe, made from a mixture of beans (ńzō) and hungry rice (cuie, Digitaria exilis). One of the men told the women they should not take the kpewe to the Dodo yet, but instead take it to the "Chief of the Women."

The previous autumn in 1964 , when I had first been introduced to the Dodo Cult at Brari Tahu, there had not been any "Chief of the Women," 
but since then the participants had been organized into a rather elaborate hierarchy modeled roughly after the tribal administration. This included not only the men who were "si zongru," that is, initiated into the cult and allowed entry into the Dodo hut, but also all the women and teen-aged girls of the compounds participating in that particular cult group. There were now three compounds affiliated with the Dodo Cult center at Brari Tahu compound: Brari Tahu, Ari Dogo, and Ari Cohu. These last two compounds belonged to the same lineage (enucie) as Brari Tahu, and were very close neighbors-about two minutes walk away. All the men and youths living in Brari Tahu (all the males older than 15 or so) had by this time been initiated into the Dodo Cult except for the two most senior men of the compound and myself-the white man living temporarily in their midst who had declined their invitation to join. ${ }^{5}$ It was explained to me that the two most senior men did not join because at their age men were seldom interested in such things, since their ritual responsibilities and failing physical vigor left them little time and strength for Dodo Cult activities. Be this as it may, they were the only two men in Brari Tahu definitely past having to care for or expecting to father any more children of their own.

The hierarchy of Dodo Cult officials which had been established at Brari Tahu by June 1965 consisted of three groups: officers for the men (initiated members), for the women (wives and elderly widows living in these three compounds), and for the girls (unmarried teen-agers). ${ }^{6}$ The officers were as follows:

I. Men (initiated Dodo Cult members) Chief (Magaji)-chosen from Ari Cohu

Second (assistant) Chief (Magaji Auhwie)-chosen from Ari Dogo Lieutenant (Likali)-chosen from Brari Tahu

Policeman (Dokali or Doli)--chosen from Brari Tahu

II. Women

III. Girls Same offices as in I.

Same offices as in I and II.

In all cases fairly popular, forthright, well-spoken personalities had been chosen for these offices, and in no case was a "Chief" selected from Brari Tahu. The initiated members had been responsible for making all the appointments, and they claimed that the Dodo himself had chosen the officers. The attendance of all the women and teen-aged girls resident in these three compounds was expected at all Dodo dances, and a major part of the responsibilities of the appointed officers, so far as I could ascertain, was checking on attendance and making sure that the women and girls frequently contributed food or drink for the Dodo dance gatherings. The involvement of people from Ari Dodo and Ari Cohu was probably reinforced by having people from these two compounds hold the highest offices in this Dodo Cult group which otherwise was so strongly identified with Brari Tahu. 
Now I return to this Dodo Dance held at Brari Tahu on the night of June 12, 1965. Around 10:30 p.m. the Dodo's reedy chanting began to float from the Dodo hut. A man appeared outside of the hut with a drum, and soon the women and girls formed the usual chanting and dancing circle in front of the hut entrance. After about ten minutes the Dodo abruptly croaked out a series of greetings to the gathered dancers and thanked them for coming. The dancing and chanting immediately stopped, and the audience responded with lavish salutations to the Dodo. Then the Dodo asked what all the trouble had been about that afternoon at Ari Dogo's when they were preparing the beer. One of the women commented wryly that it was strange the Dodo should ask since, "Didn't Dodo always know about everything that went on?" The Dodo replied tartly that indeed he did know, and repeated the question. Then after some mumbling from several women the Chief of the Women admonished a teen-aged girl in the crowd to speak up because she knew the whole story. Finally the girl began to tell what happened, first in a whisper that no one could follow, and then, after the Dodo berated her for not speaking louder, in a barely audible monotone.

The girl explained that two days before, some girls of the compound had been instructed to go down to Zaria to get firewood for beermaking for the Dodo dance. They did this, and later in the day some of the older women had also fetched wood for their own use. Then, early this morning, when they were doing the final cooking of the brew so it would have time to cool and ferment a bit more before being served in the night, they found the firewood brought by the girls was not sufficient, so the girls took some of the wood brought by the older women. Angry words ensued between the older women and the girls, the latter insisting they needed the firewood to finish the beer, and the women saying the girls could not take their wood now just because the girls had not planned ahead to have sufficient wood on hand themselves for the beer. Finally, the women grudgingly agreed that the girls could take their firewood for the beer and that the girls should replenish the supply for them later.

At this point the Dodo interrupted the girl's account with a reedy roar and upbraided the women for not giving their firewood to the girls right off. "You didn't want the girls to make beer for me! You'll be hearing more about this later," shouted the Dodo. Immediately after this the Dodo began to sing, and first the girls and then the women took up his tune and began to dance again in front of the Dodo hut.

Several minutes later the Dodo stopped his singing and bellowed that he was hungry. Everyone stopped dancing, and the Chief of the Women told the Chief of the Girls to go with several other girls and fetch the food from Dogo's compound. The Chief of the Girls said they couldn't do this, asking, "Who would lead us?" The Dodo immediately answered, "The Male Policeman," and instructed him to go with several other men to lead the girls to Ari Dogo's to get the food and then escort them back. So far as I could ascertain, this request and the arrangements for escorts was some sort of minor ritual or sham, because I had often come across girls 
in pairs or larger numbers moving freely about at all hours of even the darkest night without any escort or light, and going much further afield than Ari Dogo's was from Brari Tahu. The Policeman appointed several youths to accompany the girls, and soon they returned with jugs of beer and calabashes full of kpewe, the thick gourmet dish made of a mixture of boiled beans (ńzo) and hungry rice (cüe). Women and girls from the other compounds also brought (but without escort) the food and beer they had prepared. Then the Dodo announced that he wanted the Chief of the Women to call each woman and girl to show what she had prepared for him. One after another, first the women and then the girls were called up; each when called recovered her contribution from where she had stashed it in one or another corner of the compound and hurried with it to the Chief of the Women, who stood by a small bonfire a little to one side of the Dodo hut entranceway.

When each woman and girl had in this way shown her offering, the Dodo's voice from within the hut thanked them all, and especially praised the Chief of the Women, asking God (Nae) to bless her. Then the Dodo said he wanted only the food brought by the following people-and quickly named all the women officers. The rest, he said, should be shared by the others outside of the Dodo hut. Zabo, ${ }^{7}$ Chief of the Men, immediately stepped forward and asked the Dodo to demand silence. After the Dodo had shouted everyone to silence, the distribution of food was made, not by the Chief of the Men but by a man from Brari Tahu appointed by him to do the job.

While this distribution was going on the Dodo sang in low tones, and a couple of drummers also inside the Dodo hut beat out a gentle rhythm; the crowd outside remained quiet and still except for individuals stepping forward to take a calabash of food or pot of beer when called to do so. Three calabashes of kpewe were given to the old women, one to the Chief of the Women, ten to the women as a group, and three to the girls as a group. Next four and a half calabashes of kpewe were put aside for men in addition to what had already been taken inside of the Dodo hut "for the Dodo." The Dodo then began to chant that a calabash of kpewe should be given to the woman diviner (nevo mbru) who lived down the path at Ari Tō Tāegbaé. This woman was much respected and sought after by the women of Brari Tahu for disease diagnosis and treatment; the Dodo's suggestion was immediately taken up by the man distributing the food, and in addition to a calabash of kpewe, he put aside a small pot of beer for her.

Immediately after the food distribution, visitors from several outlying compounds stepped forward to greet the Dodo. A famous diviner and medicine man living in Miango Market announced that he had given the Dodo a gift of chicken, and he told the Policeman of the Men to go to his compound the next morning and pick it up. This diviner was originally from another tribe, but he had settled in Irigwe about twelve years before, and had built up a very large practice. The Dodo thanked the diviner very much for remembering him and for coming out in the 
cold of the night to greet him, and ordered that both food and beer be given him.

After this the Dodo again began to chant, the drummers joined in, and very soon most of the women were dancing. The area in front of the Dodo hut was so crowded by now that it was difficult to stand, let alone dance; nevertheless, people continued to shuffle around, often tripping over each other's bare feet but seldom falling, shored up as they were on all sides by other dancers.

Suddenly the Dodo roared that he missed Alya, wife of Dēmbé of Brari Tahu. "Where is she?" "Where is Alya?" "Where is Alya?" The interrupted dancers took up the refrain, until a sleepy voice out of the darkness replied, "I am here." "Where were you?" the Dodo queried. When Alya weakly answered that she had been in her hut asleep, the Dodo shrieked his annoyance, saying, "Do you not love me? How dare you sleep?" Alya protested that she had been ill and just could not stay awake. The Dodo replied that was no excuse, and besides, where had she been the week before when the girls had sponsored another Dodo dance? Alya explained that her baby had not been well and that she had been taking care of it, and that she herself had then gotten a fever. The Dodo roared that these were very poor reasons indeed for ignoring him. Alya murmured her apologies, said she would try to do better in the future, and propped herself up in a corner near the crowd of dancers but somewhat protected from their crush. The Dodo croaked that he was gratified to hear that she would do better in the future, and added that he would be watching her.

The dancing was resumed only to be interrupted a few minutes later by the Dodo shouting, "Someone bring a basket for eleusine grain!" My research assistant's name, Brae, was hononymous with the Irigwe word for eleusine grain (brae). People immediately understood the allusion, and a man elbowed the crowd aside to bring Brae a folding camp chair to sit on near the small bonfire. The Dodo then greeted Brae and asked, "Have you nothing for me? I can see just what's in your pocket, you know." Brae greeted the Dodo warmly and pulled a shilling from his pocket which he gave to a man who immediately ducked into the Dodo hut with it. "Ah, thank you," said the Dodo. "I can see you writing busily in your notebook by the light of a flashlight. I will make your head open so you can understand things." After Brae had thanked him again, the Dodo addressed the wife of Gado and asked her how her sick infant was feeling. She replied from outside the dance circle that her baby's fever had gone two days ago, and that today he was eating well again. Then she thanked the Dodo.

The dancers resumed as best they could, the crush of the crowd having gotten even greater. At one point the Chief of the Girls interrupted the dancing and led the other girls in singing a song the lyrics of which listed all the officers, men, women and girls, of the Brari Tahu Dodo group. Then they sang a lively song which recounted how Dēmbé had first brought the Dodo to Tahu.

The Dodo's chanting, the drumming and dancing were resumed and went 
on for ten to fifteen minutes; then the Dodo stopped chanting, but the drumming and dancing continued. Suddenly the Dodo's chanting was heard again, but this time it was coming from a hut about $3^{0}$ yards away next to the large open area in front of the Tahu Shrine House (Branyi Tahu). People immediately began exclaiming that the Dodo had moved to the other hut because there was more room for dancing next to it, and the crowd rapidly flowed into the larger open area in front of the Shrine Center and continued the dancing there without interruption for nearly two hours. Finally, more and more people drifted from the dance area and settled down to eat the food portioned for their group; there seemed to be plenty of beer to go with it and no public division was ever made of the beer supply. While people were eating and drinking, the Dodo's chanting stopped. All of a sudden it began again, but this time from the Dodo hut. The Dodo announced that he had returned to his hut and all the men should promptly join him there. In the dark, broken only by a dying bonfire, I could not count how many men entered the hut, but it seemed like an endless number; and perhaps a dozen were still trying to squeeze into the small hut when a second Dodo's voice was heard from back in the hut near the Shrine House. The Dodo explained that he had been joined by his brother, and immediately several pots of beer and calabashes of kpewe were passed out of the Dodo hut entranceway to the waiting men, who then went with them and entered the hut with the other Dodo. The feasting and drinking continued until nearly daybreak. On several occasions individuals on their way home from celebrations elsewhere stopped in and addressed their greetings to the Dodo. The old men were assigned three pots of beer of their own by the officers, and perhaps because this was more than they could possibly consume themselves, these casual visitors were invariably treated to beer by them. Once during the drinking, the shrill voice of the Dodo announced that a pot of beer be taken to a diviner, a twin who lived in Tāegbaé about half a mile away, who was frequently consulted by Tahu people.

As the first light of dawn was just appearing in the east, the second Dodo called that he was leaving; everyone yelled their thanks for his having come and urged him to be sure to return after the rainy season was over. Then people began to go home. They left for the most part in twos or threes, first giving a few pennies to the Chief of Women standing in front of the Dodo hut. Soon the remaining Dodo let out a yelp, and rasped "Goodbye!" The dwindling crowd chanted, "Farewell," "See you next year," etc. Within very few minutes the only people left at the scene of the celebration, besides my assistant and me, were several bleary-eyed men and women officers who were tallying up the number of contributions made to the Dodo that night. They reckoned that Brari Tahu women had contributed 19 pots of beer, Ari Dogo 14 pots, and Ari Zarami, a neighboring compound which had been invited to participate in the Dodo dance on this occasion, had brought ro pots of beer. Ari Cohu didn't contribute any beer. The officers were pleased that the total number of beer pots brought exactly equalled the number of large calabashes of kpewe contributed-43 
in all; they concluded that 43 women had attended the dance, since each woman was obliged to bring one calabash of kpewe. Each woman, in addition to the kpewe, contributed 6d, except for the women officers who were obliged to contribute one shilling each. The girls did not give any money. The beer was prepared by the women and girls of each compound and then presented as a gift from the compound rather than from each individual. The girls did a large portion of the brewing on this occasion but were excused from making any kpewe. A week earlier, however, a smaller dance had been put on for the Dodo by the girls, and they had prepared the kpewe for that occasion.

Ari Zarami was not a Tahu compound, but individuals in Zarami were very closely allied to the three other compounds through maternal links, and were considered "mother's people" (né tékwē). Thus although men from these three compounds married daughters from Ari Zamari, and vice versa, they never took each others' wives in secondary marriage, and I was told that it was likely that Zarami people would soon be asked to join the Brari Tahu Dodo group.

Ari Cohu was an unusually small compound, consisting of one middleaged man, named Zabo, his wives when they were resident with him, and his still unmarried teen-aged daughter and son. Until 1962 Zabo had resided in Brari Tahu with his senior half-brother. After a dispute, the details of which I never learned, Zabo decided no longer to farm with his brother. He built a hut and granary about roo yards east of Brari Tahu, surrounded it with its own euphorbia hedge and became, in effect, a new independent compound. He had had two wives resident with him for a number of years, but early in 1965 both wives went off to other husbands, leaving only his young unmarried daughter to cook for him and his son. Thus she had been excused from making kpewe for the Dodo dance. Zabo had been chosen "by the Dodo" to be "Chief of the Men," and his daughter, no more than fourteen years old, charming, vivacious, and very well liked by both her age peers and elders, had been made "Chief of the Girls." Zabo's daughter had the sort of personality one usually finds in Irigwe leaders other than those holding strictly ascribed positions. But Zabo did not, and I suspect that some sort of desire to reaffirm Zabo's good favor to Brari Tahu lay behind his appointment as Chief of the Men.

Later in the day following this final Dodo dance of the season, I asked a number of people who had been present to tell me more about this Dodo Cult and why it was getting so "big" now. First I was told that no more Dodo dances and feasts would be held until after the performance of the tí rū wúz $\bar{u}$ ritual next September which would make it possible once again to build bonfires outside and to drum in the out-of-doors. I was assured, however, that in the interim Dodo could be called to his hut by Brari Tahu by individual cult members for consultation. Then people insisted that if I wanted to know how Dodo first came to Brari Tahu, and why it was important, I should talk with Dēmbé, because Dēmbé, they said, brought Dodo to Tahu in the first place. I felt skeptical of Dēmbé's knowledge of Dodo. He was certainly an important man in Tahu. He was the Govern- 


\section{Exhnology}

ment Headman (Mwangwa) of the administrative Sub-district that extended from Brari Tahu to Miango Market and included most Tahu Section compounds as well as quite a few compounds belonging to other sections; also, he had five wives in residence. But Dēmbé had never taken an active part in the Dodo dances I had witnessed; indeed I had only once seen him step briefly into the Dodo hut. So I went to Dëmbé and asked him why he took so small a part in Dodo activities if, as everyone said, he was the first man to bring Dodo to Tahu. Dēmbé replied that it was true he had brought Dodo to Tahu. He asserted that Dodo was very important today, that he had been very active in Dodo affairs in former times, but that he left most of these to others now. Since Dēmbé offered no further explanation of his minimal present-day participation in Dodo, I was left wondering whether he was being cautious about jeopardizing his administrative position and was waiting until Dodo was more securely re-established by the administration as a legitimate activity before resuming a more active role in Dodo affairs.

Dēmbé's account to me of the origin and importance of Dodo to Tahu can be summarized as follows:

When Dēmbé was about eight or nine years old, he fell chronically ill, lost weight, and grew listless. Finally his father, named Ilo, in desperation decided to take Démbé to see the Dodo down in Chawai, ${ }^{8}$ because people had told him that perhaps the Dodo could help his son. Chawai is the tribe neighboring Irigwe to the west, in Zaria Province; its border lies around Io or I2 miles away from Brari Tahu, down the escarpment. Dèmbé and Ilo stayed in Chawai at the home of the Dodo for several months and Dëmbé grew progressively stronger and healthier. Then quite suddenly after he had recovered fully, Démbé says the Dodo decided he "wanted" him, and the Dodo "swallowed" him (á ungwárä)! Dèmbé says his corpse lay lifeless for two hours. Ilo paid the Dodo three cocks (idaemvwe) and one castrated goat (se), and in return the Dodo brought Dēmbé back to life. Dēmbé, fully recovered, then returned to Irigwe with his father, but always after that, whenever there was going to be a major ceremony the Dodo called Dèmbé to come down to Chawai to participate. Finally, after many years, the Dodo permitted Dëmbé to "buy" him for two she goats and two big cans (eight imperial gallons) of beer. A dozen men came up from Chawai with the Dodo, Dėmbé recalls, held a big ceremony and spent the night at Brari Tahu, and asserted that thenceforth the Dodo would stay there-i.e., come to Dèmbé whenever called. This was quite a few years ago, long before the Administration's ban was placed on Dodo activities in Irigwe.

Dēmbé assured me that Dodo was bigger than any diviner or medical practitioner, especially in dealing with troublesome witches. The Dodo can "sniff out a witch" ( $y \bar{u} k r o \bar{t} u \dot{u})$. At first the Dodo does not reveal the name of the witch, but if he has to sniff out a witch a second time he will let the name be known, asserted Dèmbé. Then the men initiated into the cult warn the witch that if the person being troubled by the witch does not recover, the Dodo will kill the witch.

Dēmbé said that witches used to devour people $(y e ́ n \bar{e})$, but they do not anymore, because they know the Dodo will get them. Also people used to see fires burning where there were no people to set the fire, but not nowbecause the Dodo has stopped this also. And now that the Government 
was permitting Dodo celebrations again, the control of witches would be even further assurred, Dēmbé declared.

\section{Conclusions}

Western anthropologists are so conditioned to view social change either in terms of acculturation towards and accommodation to a western political and industrial infrastructure, or in terms of movement towards the urban end of a folk-urban continuum, that innovations not distinctly of a "western" or "urban" nature tend to be unnoticed or glossed over as trivia. Tribes such as the Irigwe which have retained much of the cultural and social fabric of their pre-European life style, even though exposed to two or more generations of western political overrule, missionization, and economic influence, are termed "remarkably conservative," "strongly traditionalist," and the like. In the case of the Irigwe, however, evidence abounds that the tribe has experienced profound changes in many spheres of life since it was first pacified by the British in 1905. Some of the most striking changes are not readily apparent to the European because they involve or center around the acceptance and utilization of cultural elements borrowed from nearby groups, rather than from Europeans. In some cases, however, this borrowing can be traced to new conditions induced by the European presence. The establishment of effective British over-rule, for example, not only facilitated peaceful interaction with formerly "enemy" neighboring tribes, but in some cases led to the development of conditions which made certain alien customs desirable and sought after. Such is the case of the Dodo Cult, which the Irigwe are now borrowing from the neighboring Chawai people and espousing in their own terms with evangelical fervor.

The principal avowed motive that the Irigwe have for adopting the Dodo Cult is that it is very helpful and effective in controlling witches (krotu) who bring illness. It is probable that the Irigwe have for many generations believed that krotu were a major cause of disease and death; certainly all evidence indicates that this belief was well established as far back as the memory span of the oldest living Irigwe, i.e., well before 1905, the date of the British intrusion into the area. An examination of what sorts of diseases are believed to be caused by witches and what steps traditionally are taken to control and prevent these diseases reveals that the child-bearing capacity of young women, and the health of infants and small children are felt to be the prime targets of witches. There are many long established and widely used ways of controlling the depredations of witchcraft, ranging from the widespread wearing of protective amulets to very rare open accusations of witch suspects by lineage and section elders, followed by doctoring of the suspect to neutralize the evil powers or expulsion of the suspect from the local community by one means or another. In the case of infants believed to be victims of witchcraft, however, the most usual step so far as I could ascertain, other than placing a protective amulet around the baby's waist, is for the mother simply to move off to another 
secondary husband taking her small children with her. Why then the present-day utilization of an alien cult to control the depredations of witches? Is this merely a case of the Irigwe now having access to this cult where prior to pax britannica they did not? Clearly not. The Chawai were a "friendly" neighbor, a people with whom the Irigwe were on good terms for as long as can be recalled, and against whom there is no memory of headhunting or fighting. Also I found no evidence either direct or indirect that an actual increase of illness imputed to witchcraft, or of overt witchcraft accusations, had occurred in recent years. Thus I think we must look to recent shifts in the structural regularities of Irigwe society which might result in such an organizational innovation as the recent widespread establishment and acceptance of Dodo Cult groups in Irigwe. ${ }^{9}$

Elsewhere (Sangree 1972: 1239-42) I have shown that the effective development and present-day functioning of the British-instigated Irigwe tribal administration has rendered superfluous the intra-tribal peace-keeping functions of the co-husband bonds resulting from secondary marriage. Another aspect, an undesirable side effect, so to speak, of secondary marriage in Irigwe is the frequent squabbles between men, when one of them is courting or suspected of courting a wife of the other. Formerly the Irigwe were willing to put up with these squabbles, indeed they had no good alternative; but now that tribal peace is assured by the tribal administration, people are less willing to tolerate them. Efforts to curtail these disputes by discouraging secondary marriage culminated in 1968 in tribal legislation making secondary marriage in its traditional form illegal, and requiring a woman to obtain a divorce from her previous husband before marrying and taking up residence with another husband. With this traditional method of escaping witchcraft's depredations thus greatly diminished, alternate methods of witchcraft control very likely seemed increasingly attractive; and this is precisely what the Dodo Cult affords in Irigwe eyesan alternate effective means of witchcraft control.

It is noteworthy that the Dodo Cults in Irigwe, particularly those with organized women's auxiliaries such as the one at Tahu, engage resident wives more deeply in the ceremonial and social life of the husband's section and lineage than they would otherwise be. An Irigwe husband occasionally farms a field exclusively for the personal harvest and profit of a wife whom he wishes to please and entice to stay with him, or to return quickly from sojourns with any of her other husbands (Muller \& Sangree 1973: 56). Also, he may perform expensive possession (rije) cult ceremonials for her for the same reasons (Sangree 1969: 1056). Senior wives (daebranyi) of important section elders also have important roles to play in section and lineage ceremonials. With these three exceptions, however, an Irigwe wife has little participation in or reason to identify with the major social activities of her husbands' sections and lineages beyond the immediate circle of resident co-wives (reuri) with whom she shares everyday domestic chores. The growth of Dodo Cults may well have been spurred not only by the widely proclaimed need to dispel witches, but also by the hope sometimes voiced by the men that they might be able to keep more of 
their wives from moving on to other husbands so frequently and for so long by supplying them with a ready alternative to a change of residence as a way of allaying their fears of witchcraft through Dodo cult activities. One man in Brari Tahu compound told me that in 1963 and 1964 prior to their renewing Dodo Cult activities in Brari Tahu they had been losing more wives than they had been gaining, but now (1965) their wives were staying with them more and more. Also, he said that several nearby compounds of other sections had noted Brari Tahu's success in this regard and were laying plans to establish Dodo Cult groups of their own. I had taken a census of Brari Tahu shortly before the cult's renaissance there and thus was able to confirm that indeed the ratio of resident wives per married man in Brari Tahu had increased since the cult group's reactivation. Unfortunately, my period of field work ended in Irigwe before I could check on the possible coincidence of Dodo Cult group activity and an increase of the resident wife ratio in other compounds.

It remains a moot question whether the advent of the Dodo Cult was actually a factor in decreasing the movement of wives from one husband to another. There is much evidence, however, that my informant's statement reflected the hope, if not the calculations, of an increasing number of Irigwe-namely, the hope that the development of a vigorous and active Dodo Cult group in their local area would aid them in the perennial competition with men of other sections to attract and keep as many wives as possible resident with them locally.

\section{NOTES}

I. This is a revision and expansion of a paper read at the American Anthropological Association Annual Meeting at New York, November 197I. Suggestions made to me by Dr. Jean-Claude Muller were of particular aid. Special thanks are accorded to Mr. Moses Brae Goji. The field research on which this article is based was carried out between August 1963 and July 1965 and was funded by a grant from the National Science Foundation.

2. "Dodo" is a generic term in Hausa for "masked dancer." Both "dodo dancers" and the cults which sustained them served different purposes in the various tribes in northern Nigeria and elsewhere which had them before British conquest.

3. See Gunn (1953) for scattered references to Dodo Cult activities in various Plateau area tribes both in the former Plateau and in Zaria Provinces.

4. These are probably made from the dried leaves of the bush-banana tree (Musa sapientium). See Conant (1963: 229-30) for a reference to a similar costume among the Barawa and Bankalawa-Jarawa east of Irigwe.

5. Early in 1965 a delegation of Dodo Cult members from Brari Tahu, the compound where I had my hut and where I had attended the Dodo meetings, had invited me to join the Dodo Cult, saying that if I agreed, and would be ready to supply the goat, six shillings, and two chickens, they could soon arrange for my initiation. I asked them whether it was not true that once you had joined Dodo you were pledged never to reveal to outsiders anything about what went on in the hut. They affirmed that this was true. I asked whether it might not hinder my work of recording and writing down their history and customs for all to read if I were to join. They said that yes it might, so I replied that interested as I was in joining, and pleased as I was to be asked, I thought it would be better if I declined. They said they understood my problem, and seemed happy to accept my decision not to join the cult, and suggested that 1 simply attend and learn what I could as an outsider.

6. It is noteworthy, I believe, that the Irigwe made a distinction in this organization 


\section{EthNologY}

between wives-women ( $m b r u$ ) and girls (arewena)-i.e., a distinction between marriedin wives with agnatic affiliations elsewhere, and unmarried daughters still living in their parental homes. In contrast, the men and boys who were members of the cult were all lumped together, which is in keeping with Irigwe patri-virilocal residence patterns.

7. Pseudonyms are used throughout to protect the identity of individuals.

8. Gunn (I953: 59) states there is no Chawai Dodo cult. A number of Irigwe in formants, however, assured me that the Irigwe had obtained Dodo from Chawai.

9. I am making a distinction between "social structure" and "social organization" consonant with that made by Firth (1954).

\section{BIBLIOGRAPHY}

Conant, F. 1963. The Manipulation of Ritual Among Plateau Nigerians. Africa 33 (3): $227-236$.

Firth, R. 1954. Social Organization and Social Change. Journal of the Royal Anthropological Institute of Great Britain and Ireland 84: I-20.

Gunn, D. 1953. Peoples of the Plateau Area of Northern Nigeria. Ethnographic Survey of Africa, ed. D. Forde, Western Africa, Part VII. London.

Muller, J-C, and W. H. Sangree. I973. Irigwe and Rukuba Marriage: A Comparison. The Canadian Journal of African Studies 7 (I): 27-57.

Sangree, W. 1969. Going Home to Mother: Traditional Marriage Among the Irigwe of Benue-Plateau State, Nigeria. American Anthropologist 71: 1046-1057. 1970. Tribal Ritual, Leadership, and the Mortality Rate in Irigwe, Northern Nigeria. Southwestern Journal of Anthropology 26 (I): 32-39.

I97I. La gémellité et le principe d'ambiguité: Commandement, sorcellerie et maladie chez les Irigwe (Nigeria). L'Homme I I (3): 64-70.

1972. Secondary Marriage and Tribal Solidarity in Irigwe, Nigeria. American Anthropologist 74: I 234-I 243.

1974. Prescriptive Polygamy and Complementary Filiation in a West African Society. Man (in press) 
Reprinted from

ETHNOLOGY

Volume XIII, No. 3, July, 1974 
